\title{
Triosephosphate Isomerase
}

National Cancer Institute

\section{Source}

National Cancer Institute. Triosephosphate Isomerase. NCI Thesaurus. Code C105559.

Triosephosphate isomerase (286 aa, $\sim 31 \mathrm{kDa}$ ) is encoded by the human TPI1 gene. This protein plays a role in the isomerization of glyceraldehydes in both glycolysis and gluconeogenesis. 